\title{
Sustainability of post-mining land use and ecotourism
}

\author{
Herdis Herdiansyah $^{1 *}$; Marikha Ulfah Utami' ${ }^{1}$ Joko Tri Haryanto \\ ${ }^{1)}$ School of Environmental Sciences, Universitas Indonesia \\ 2) Center for Climate Change Financing and Multilateral Policy, Fiscal Policy Agency \\ Ministry of Finance of the Republic of Indonesia \\ *Towhom correspondence should be addressed.Email: herdis@ui.ac.id
}

\begin{abstract}
The mining sector can contribute to the state in the form of foreign exchange and state in the form of foreign exchange and funding sources such as royalties, taxes, the expansion of employment and physical development, on the other hand, led to some social and environmental conflicts. One effort to improve environmental conditions in the mining area through revegetation, reclamation and post-mining. Reclamation and post-mining activities must be under the EIA plan, FS, Plans Closure Reclamation and Mine Closure Plan to be used for sustainability and ecotourism. This study was conducted using a collaboration between study literature method and the AHP method. The purpose of this study was to determine the post-mining land use, preferred alternatives for utilization of post-mining land is done through the Analytical Hierarchy Process (AHP) method by analyzing the relationship between three criteria and alternatives. The criteria are selected based on the ecological, socioeconomic and cultural aspects. This is based on the consideration of sustainability and spatial planning. In addition, the alternatives that will be considered as utilization strategies include the efforts to increase the land use.. Secondary data analysis resulted that known to the utilization of post-mining land from various companies such as: the use of pits (void) into water treatment, aquaculture and ecotourism, the usage of land reclamation and mine closure in the form of plateau used as cultivation flora and fauna depends on the utilization zone, which has approved the EIA Document, FS, Plans Closure Reclamation and Mine Closure Plan.
\end{abstract}

Keywords: post-mining reclamation, land use, mining, sustainability

JEL Classification: Q24, Q56, Z32

\section{INTRODUCTION}

Environmentally friendly construction nowadays becomes a necessity for any country that wants the preservation of natural resources and for the welfare of the people on an ongoing basis is also needed natural resources exploited for consumption. Therefore, the natural resources that will be used must be appropriate, protected and preserved for the survival of present and future generations (Arif, 2007), as well as appropriate and as efficiently, exploited so that it can be enjoyed by people much quicker and affordable. Development is done cannot be denied changing the cover or land use which will result in the deforestation in an area at a particular time. For example, the exploitation of the forest land in a specific region which contains abundant natural resources (SIH 2013) for an extended period resulting an impact of the decreasing flora and fauna (Sandin, 2009), air pollution (Hu et al.2008), climate change caused by global warming (Trisasongko, et al., 2009). It is also more common in the 
expansion region (Tuni, 2013) and the mining area of oil and gas well, mineral and coal (Gunawan et al., 2010).

In this article, the mining sector can contribute to the state in the form of foreign exchange and the various sources of funding countries such as royalties, taxes, and the expansion of employment and physical development, but on the other hand based on the results of research of LIPI (2006), mining activities have caused a number of social conflicts and the environment. Environmental damage resulting from mining activities that intentionally removes vegetation, transforming the landscape, change the composition of the soil which can cause erosion, sedimentation, soil nutrients and soil compaction can lead to land degradation. One effort to improve environmental conditions in the mining area is through reclamation and post-mining activities.

Reclamation is one of a series of mining activities conducted throughout the stages of venture mining activities which aim to organize, restore and improve the quality of the environment and ecosystems to function in accordance designation. In Government Regulation Number 78 Year 2010 regarding Reclamation and Mine Closure, that the reclamation plan includes: a) Land use before and after mined; b) Land clearing plan; c) Program reclaim disturbed land cover, and land mined lands outside the former mine who is temporary and permanent; d) Success criteria include the standard for land arrangement, civil works, and finishing; and e) Reclamation plan costs consist of direct costs and indirect costs.

While the post-mining is an activity planned, systematic, and continue after the end of the part or all mining activities to restore the function of the natural environment and social tasks according to the local conditions in the mining area, the definition in accordance to Law No. 4 of 2009 on Mineral and Coal. Efforts need to be made referring to the principles of post-mining, include: 1) quality of surface water, sea water, groundwater, and air according to environmental quality standards; 2) Slope stability and security pile of overburden, tailings dams, mined land and artificial structures (human-made structure) others; 3) Biodiversity; 4) Ex-mining land use in the manner intended and consider social, cultural, and economic.

Reclamation and post-mining land can be utilized in the manner intended and following the EIA, feasibility study (FS), the plan of reclamation and mine closure plan, regarding the principle of mining good mining practices and policies for the reclamation and post-mining community sustainability. Besides, the post-mining land use should be appropriate and consistent with the Spatial Plan (RTRW) in a region with still referring to the National Strategic Areas (KSN). KSN designated area of the national strategy is the area of which there are examples of strategic natural resources such as oil and gas Surefire resources, mineral and coal where natural resources can support the economy. The mining area is in a protected area (nature reserve, re-forest ecosystems, protected areas) do not get forest land use permit to perform well exploration and exploitation of mineral and coal. Under Article 38 Paragraph 4 of Law No. 41 of 1999 on Forestry, that the protected forest areas are not allowed or prohibited from conducting mining or exploitation by open pit mining system. Therefore, in this article, I will discuss the postmining land use and designation Other Use Areas Protected Forest outside the mining area.

\section{METHODS}

This study was conducted using a collaboration between study literature method and the AHP method. The purpose of this study was to determine the post-mining land use. Data have been obtained will be reviewed in more detail to strengthen existing data. 
In this research, preferred alternatives for utilization of post-mining land is done through the Analytical Hierarchy Process (AHP) method by analyzing the relationship between three criteria and alternatives (Saaty, 2008). The criteria are selected based on the ecological, socioeconomic and cultural aspects. This is based on the consideration of sustainability and spatial planning. In addition, the alternatives that will be considered as utilization strategies include the efforts to increase the land use. The ecological criteria indicate that the post-mining land use considers the ecological sustainability. Furthermore, the socioeconomic factor shows that the selected alternatives are the ones that beneficial among community around the sites which the advantages are not solely material. The utilization should consider the cultural factor, to measure the magnitude of the land use to the sustainability of the culture to achieve maximum results.

Some alternatives that were analyzed are as follows: the first alternative is to build the water treatment, the second one is to develop aquaculture and ecotourism zone. The last alternative is to build a flora and fauna conservation zone. Determination of these alternatives is based on the concept following the statement of Ross \& Wall (1999) that nature can help the environment harmonization between conservation areas and sustainable development aimed areas which utilize both economic values of ecosystems/ environment for the well-being of communities around the mine and can keep the preservation of the environment. The strategy undertaken by the government has become more normative thus a breakthrough for more effective implementation in post-mining land use is needed. Figure 1 described the hierarchy model used in this study.

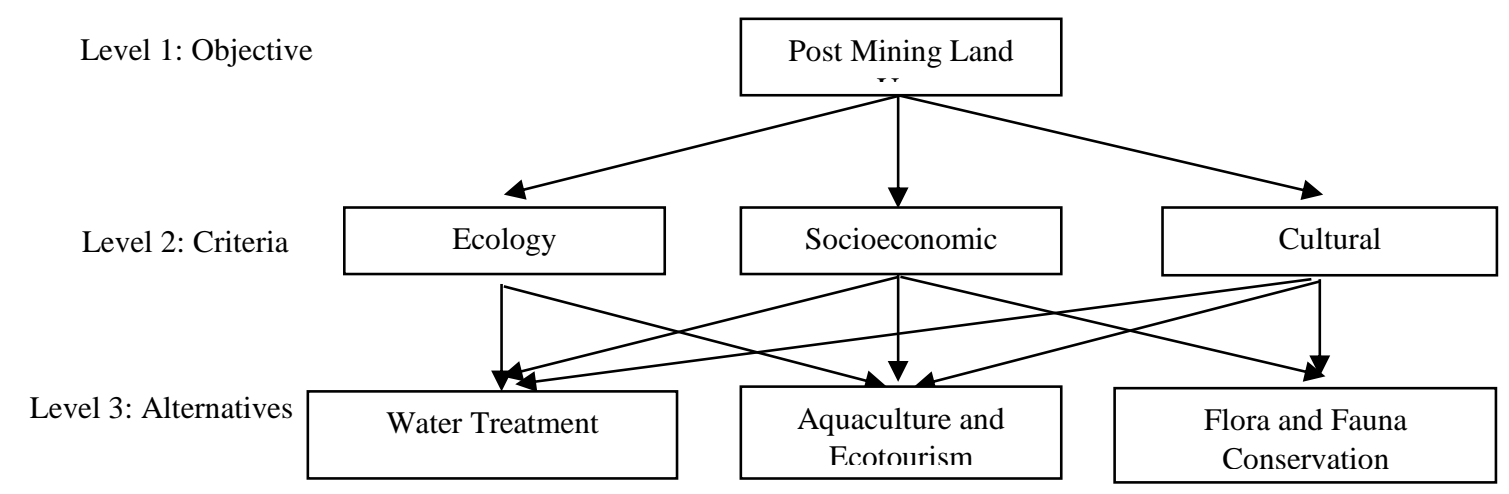

Figure 1. The hierarchy for The Post-Mining Land Utilization Strategies

\section{RESULTS AND DISCUSSION}

As elaborated, the priority of the alternative strategy is to be determined through a comparison concerning each criterion. The value of the criteria and alternatives are determined to meet the outcome of developing the post-mining land utilization. This analysis is based on a multidisciplinary approach to the study of literature studies, including studies of socioeconomic, environment, cultural basis, and technology.

Table 1. Pairwise comparison between criteria and objective

\begin{tabular}{lrrccc}
\hline Post mining land use & Ecology & Social & Cultural & Percentage (\%) & Ranks \\
\hline Ecology & 1 & 3 & 7 & 65.86 & 1 \\
Socioeconomic & 0.333 & 1 & 4 & 26.28 & 2 \\
Cultural & 0.143 & 0,250 & 1 & 7.86 & 3 \\
\hline Consistency ratio & & \multicolumn{5}{c}{0,031} \\
\hline Sour
\end{tabular}

Source: results of data analysis, 2018 
Based on the results of the pair-wise comparison in Table 1 in respect to the criteria to determine the objective of the selection of the post-mining land use strategies, it was found that the ecology criteria are a priority with the result of $65.86 \%$. Utilization of post-mining land through reclamation and post-mining activities may include soil fertility improvement activities (reclamation and revegetation of mined land) and water quality improvement pits (void). Post-mining land use may be nature, landscapes, cultivation of biodiversity of flora and fauna. Criteria Region former mine which can be used for sustainability depends on the structure and shape landscape view of its natural conditions, i.e. ex-mine made basin in the form of pits that resemble lakes, hills or steep cliffs and fields that have been successful in reclaiming and revegetation (Arifman, et. al., 2013). Therefore, the results of the AHP/ANP assessment proves that the ecology factors need to be the basis for the choice of the post-mining land utilization strategies. Consistency ratio of $3.10 \%(0,031)$ indicated that the results of the analysis are valid by the requirements $(<10 \%)$ (Saaty, 2008). This method deals with subjective judgment, and it may include a high degree of inconsistency. Saaty (1998) proposed to analyze Consistency Ratio by comparing the Consistency Index to Random Consistency Index. If Consistency Ratio is equal to or less than $10 \%$ or 0.01 , then the result is categorized as consistent and acceptable (Saaty, 1998).

Table 2. Pairwise comparison between criteria and alternatives

\begin{tabular}{|c|c|c|c|c|c|c|c|c|c|c|c|c|}
\hline \multirow{2}{*}{$\begin{array}{l}\text { Post Mining } \\
\text { Land Use }\end{array}$} & \multicolumn{4}{|c|}{ Ecology } & \multicolumn{4}{|c|}{ Socioeconomic } & \multicolumn{4}{|c|}{ Cultural } \\
\hline & WT & $\mathrm{AE}$ & FF & Total & WT & $\mathrm{AE}$ & FF & Total & WT & $\mathrm{AE}$ & FF & Total \\
\hline WT & 1 & 0.200 & 3 & 0.188 & 1 & 0.333 & 4 & 0.279 & 1 & 0.333 & 3 & 0.258 \\
\hline $\mathrm{AE}$ & 5 & 1 & 7 & 0.731 & 3 & 1 & 5 & 0.627 & 3 & 1 & 5 & 0.637 \\
\hline FF & 0.333 & 0.143 & 1 & 0.081 & 0.250 & 0.200 & 1 & 0.094 & 0.333 & 0.200 & 1 & 0.105 \\
\hline $\begin{array}{c}\text { Consistency } \\
\text { Ratio }\end{array}$ & \multicolumn{4}{|c|}{0.062} & \multicolumn{4}{|c|}{0.082} & \multicolumn{4}{|c|}{0.037} \\
\hline
\end{tabular}

Note: WT=Water Treatment; $\mathrm{AE}=$ Aquaculture and Ecotourism; FF=Flora and Fauna Conservation

Source: results of data analysis, 2018

Furthermore, the pair-wise comparison assessment of alternative strategies is to determine which utilization strategy is a priority. Table 2 is the result of pair-wise comparison analysis between alternatives for the criteria to determine priority postmining utilization strategies. In this study, all analyses were performed using Superdecision ver 2.6 software. Based on the result of pair-wise comparison between alternatives to each criterion, it was found that the development of aquaculture and ecotourism in the post-mining land becomes the leading alternative on each criterion, followed by the establishment of water treatment and project of flora and fauna conservation. The alternative for aquaculture and ecotourism development showed results sequentially by $73.1 \%$ (ecology criteria), $62.7 \%$ (socioeconomic criteria), and $63,7 \%$ (cultural criteria). The second option is a water treatment establishment, which showed the results consecutively are $18.8 \%$ (ecology criteria), $27.9 \%$ (socioeconomic criteria), and $25,8 \%$ (cultural criteria). The next approach is the conservation project of flora and fauna with the results of $8.1 \%$ (ecology criteria), 9.4\% (socioeconomic criteria), and $10,5 \%$ (cultural criteria). The three results of the analysis are eligible because all results show consistency ratio of $<10 \%$. 
Table 3. The result of AHP method

\begin{tabular}{cccc}
\hline Post Mining Land Use & Total & Normal & Ranking \\
\hline WT & 0,1089 & 0,2179 & 2 \\
AE & 0,3480 & 0,6960 & 1 \\
FF & 0,0431 & 0,0862 & 3 \\
\hline
\end{tabular}

Note: WT=Water Treatment; AE=Aquaculture \& Ecotourism; FF=Flora \& Fauna Conservation Source: results of data analysis, 2018

Priority prevention strategies that are selected sequentially are shown in Table 3. As mention before, the development of aquaculture and ecotourism becomes a top priority to the strategy of post-mining land use utilization. This is in line with the condition where the current utilization strategy implemented in some sites in Indonesia.

\section{Coal mining and land use ex-mining}

According to Tushar \& Mark (2009), a technique that is used to exploit the mining of coal is very dependent on the quality, depth of coal seams and geological structure of coal resources and reserves itself. In this case, the coal mining process can be grouped into two categories: Surface Mining and Underground Mining. In general, many coal mines in Indonesia uses a system of open pit mining (surface mining). Openpit mining system with mining methods open pit mining prevalent in almost all the coal mining areas in Indonesia. Each stage of mining activities such as (a) exploration: drilling activities to search, specify the amount of resources and reserves, including the form of the formation, size, location and the quality or grade of minerals and coal; (b) land clearing: activities of clearing of shrubs and trees; (c) the exploitation associated overburden cover (overburden) and coal getting (Hartman, 1987). In the mining area, mining has a severe influence on the transformation of land use, which in turn determines the response of different ecological (Zhang et al., 2010).

In general, open-cast mining activities (open-pit mining) would result in environmental damage in the form of a decrease in surface soil structure, soil, and vegetation. Surface soil or topsoil is placed in an area with no regard to the technical aspects as well as the implementation of the revegetation and reclamation are not good will lead to a reduction or change in physical and chemical fields, such as changes in the form of rocks, decreased quality of nutrients and slope instability that would result in soil landslides, erosion. As one explicit impact, that subsidence can cause structural changes in the land surface and vegetation, which affects the surface of the land use and landscape (Zhang et al., 2011). This proves that the plant recovery after mining seems slow and qualitatively lower than the regeneration after the use of land for other activities (Peterson \& Heemskerk, 2001). It can be concluded that the use of an area is one of the determinants of primary environmental gradients (Cooper et al., 2006). So that the damaged mining land being targeted for restoration and use, with the purpose of the land can be used for the future. Planning and landscape restoration for use in the post-mining land can be a redistribution of industry, including agriculture, forestry, fisheries, tourism, cultural industries, and so on.

According to Dewi (2011), the landscape is a preliminary description of a planning development of nature tourism with the aim to learn visually and enjoy the view (flora, fauna and socio-cultural). In the specific area of planning, need to be inventoried and some data out information in the form of the structure, properties, layout, symptoms of which would be caused by changes in the region. According to Arifman, et. Al (2013) used a natural tourist area in landscape planning approach potential to protect the environment and improve the quality of the environment sector in the region. 
However, to landscape planning viable, and sustainable firstly need any EIA, feasibility studies, plans reclamation and mine closure program in landscape planning area of the former coal mine contained into the reclamation and mine closure plans both in the planning of mined land into a tourist area natural, urban areas, aquaculture, plantations or farms.

According to Dr. A. Robertson \& S. Shaw (in the book Mine Closure), stated that the planned closure, there are four main objectives to be considered: The main purpose of the planned closure (A. Robertson \& S. Shaw), is: 1) Protecting public health and safety; 2) Relieve or eliminate damage to the environment; 3) Achieve productive land use, or returned to its original condition or an acceptable alternative; and 4) the extent possible, provide sustainable social and economic benefits as a result of mine development and operations.

\section{Zones land mine closure}

Determination development zone of an area of land reclamation and mine closure specified in EIA documents, Feasibility Studies, Plans Reclamation and Mine Closure Plan well into nature tourism, cultivated areas, and other areas, it is determined based on the starting zone of the mining area and the division of the zone designation. Landscape ecology focuses on the structure, composition, and its purpose (McGarigal, 2001). Three principles to realize a corresponding landscape planning is spatial patterns, a large extent, and role of humans (McGarigal, 2001).

Kim et al. (1991) in the Goddess (2011) split 4 landscape development zone according to the type of land suitability, namely: a) Zone Potential Scenic is a zone that has the potential diversity of visual interest. The diversity that is the center of attention consists of stands of vegetation, flora, and fauna, bodies of water. Where the area has the potential for the use of the natural attractions in the form of stands of vegetation and water tourism and other uses; b) Cultivation and Education Zone is a zone devoted to farming, such as aquaculture, beef, lamb, mushroom cultivation, fruit and more. Spatial data, land use and cultivation of the data needed to plan the cultivation and education zone. Besides Raising this region serves as a passive education and recreation zone; c) Recreation zone is a zone for nature tourism activities, entertainment, and a playground. To preserve the resource in this zone several attempts namely by limiting the number of visitors, setting the frequency of visits, make regulations maintenance and preservation of the environment in the area of recreation, sanctions related to the destruction and pollution of the environment and other businesses to preserve the ecology and conservation recreation zone. Data spatial and land use, form, structure, land, soil, water and area restrictions are needed to plan this recreation zone; d) Conservation Zone is a zone is an area where the preservation and protection of the area must be managed and utilized wisely because this zone is susceptible to natural changes caused by human activity so that this region is also known as a counterweight to other areas. Flood-prone area, the river, and its flow pattern, Special Natural Area, is a water catchment area component of the conservation zone.

But in the field of applications, land use zones of each company is different former land use zones, e.g. PT Bukit Asam is divided into 12 zones, namely: Planted Forest Zone; Productive Research Zone; Zone Infrastructure; Zona Gardens Collections; Zone Receiver / Recreation; Air Travel Zone; Zone Ranch; Agricultural Zone / Agroforestry; Animal zone: Zone Orchard; Campgrounds zone; and Fishing Zone. Utilization zones mined lands such, must comply with the FS, EIA, Reclamation Plan and Mine Closure Plan has been consulted by the government and society. 
In general, post-mining areas in Indonesia in the form of reclamation plain or used as the cultivation of flora and fauna, while open holes due to mining process (void) can be utilized for sustainable sources of clean water for local communities following the utilized zones, as follows:

a. Zone Scenic potential, some examples of the utilization of mined land that has the potential for sustainability and nature, among others:

1. A Case Study in PT Bukit Asam Sawalunto (Arifman, et. al., 2013), the results of reclamation activities of sight viewing that can be developed with walking down the hills of the former coal mine that has changed with the various stands of vegetation, fruit garden has been an active and visible range of colors, and the ex-mine lake.

2. Development area camping in the former mining area of PT Bukit Asam Sawalunto, in the area can be done hiking, can also be a place of rest for the tourists who walk and local artistry.

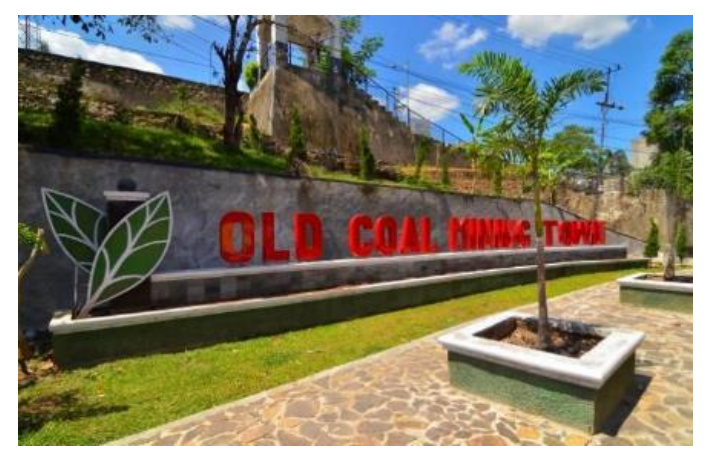

(a)

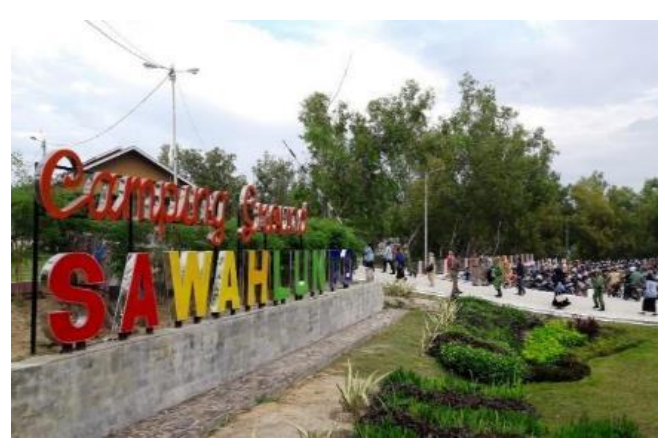

(b)

Figure 2. (a) Old coal mining town; (b) Camping ground Sawahlunto

3. Activities PT Adaro Indonesia, South Kalimantan Province which utilize hole Ex-Mine (Void) for sustainable development in the use of water for the people to not neglect either the metal content of the soil and water (Nurcahyani, 2011).

4. Case Study PT Adaro Indonesia in addition to using the water from pits(void), PT Adaro Indonesia also utilize wastewater, and the wastewater from the use of mining activities of PT Adaro processed through the treatment process which is equipped with a settling pond at each mine site ( Adaro Indonesia, 2010).

A total number of water treatment ponds at each mine site as much as 50 pools of waste treatment. From the diagram of water use and water treatment in a mining area of PT Adaro, the water used comes from rainwater and water that was in the mining pit ago flowed into the settling pond (settling ponds). From the settling pond water is reused for mining activities are for watering mining roads which aims to reduce dust pollution, and part of water that is in conformity with the environmental quality standard flowed into water bodies and partly processed by using a water treatment plant and clean water that can be consumed is ready to be distributed by truck or pipeline to the communities around the mine. 


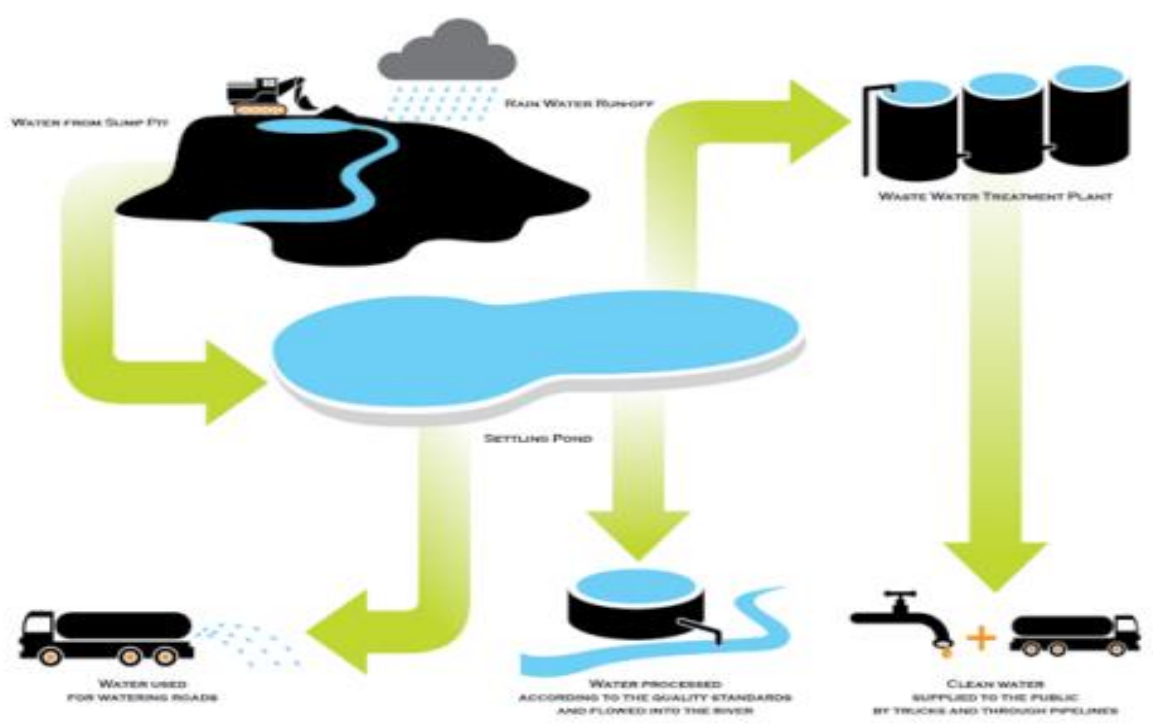

Figure 3. Diagram of the water usage and treatment in mining sites

PT Adaro builds a water treatment facility Water Treatment Plant (WTP) T.300, which can be used as clean water for both the company and society. Clean treated water dispensed to 1,110 heads of families in eight villages around Adaro Mine area. Even for the Dahai and Padang Panjang village, Adaro distributes clean water directly to homes via truck, tanker trucks by facilitating water tank adequate because the villages were distant and unreachable by pipeline built by Pt Adaro round 10 kilometers. Following the document of the pipeline management closure plan will be submitted to Clean Water Agency (Bapel-AB) to be distributed to the public, it also is sustainability and reduces community dependence on PT Adaro Indonesia.

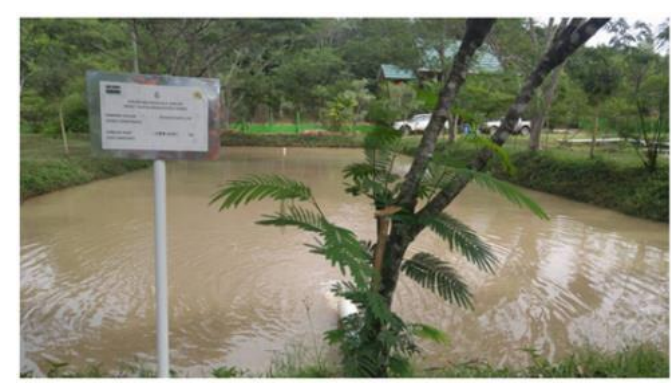

(a)

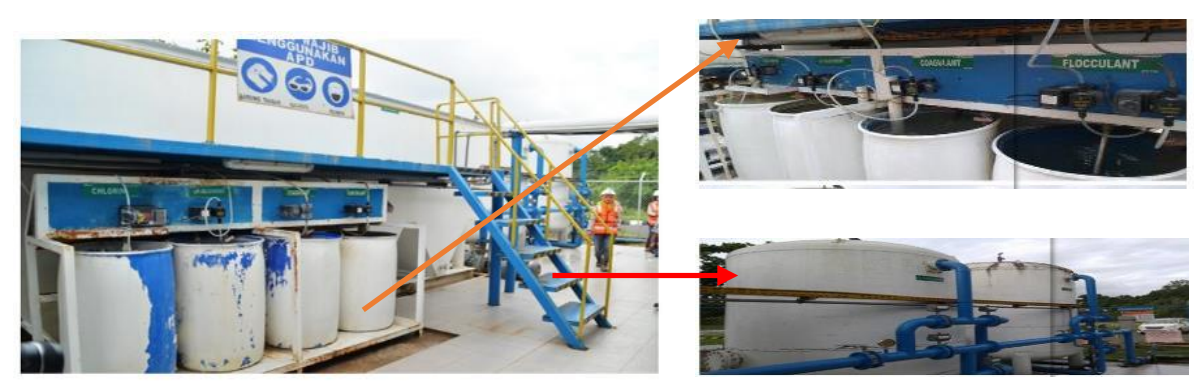

(b)

Figure 4. (a) The pool precipitator; (b) Water Treatment Plant (WTP) 
5. Activities of PT Kaltim Prima Coal, which utilizes Hole Ex-Mine (Void) for sustainable development in partnership with the Regional Water Company (PDAM) in the management of clean water for the surrounding communities in the region Sanggata, East Kalimantan with affordable and equitable (can be enjoyed by the public many). This contributes in the form of income for the area and cleans water resources for the communities around the mine. Source water comes from Telaga Batu Arang as follows:

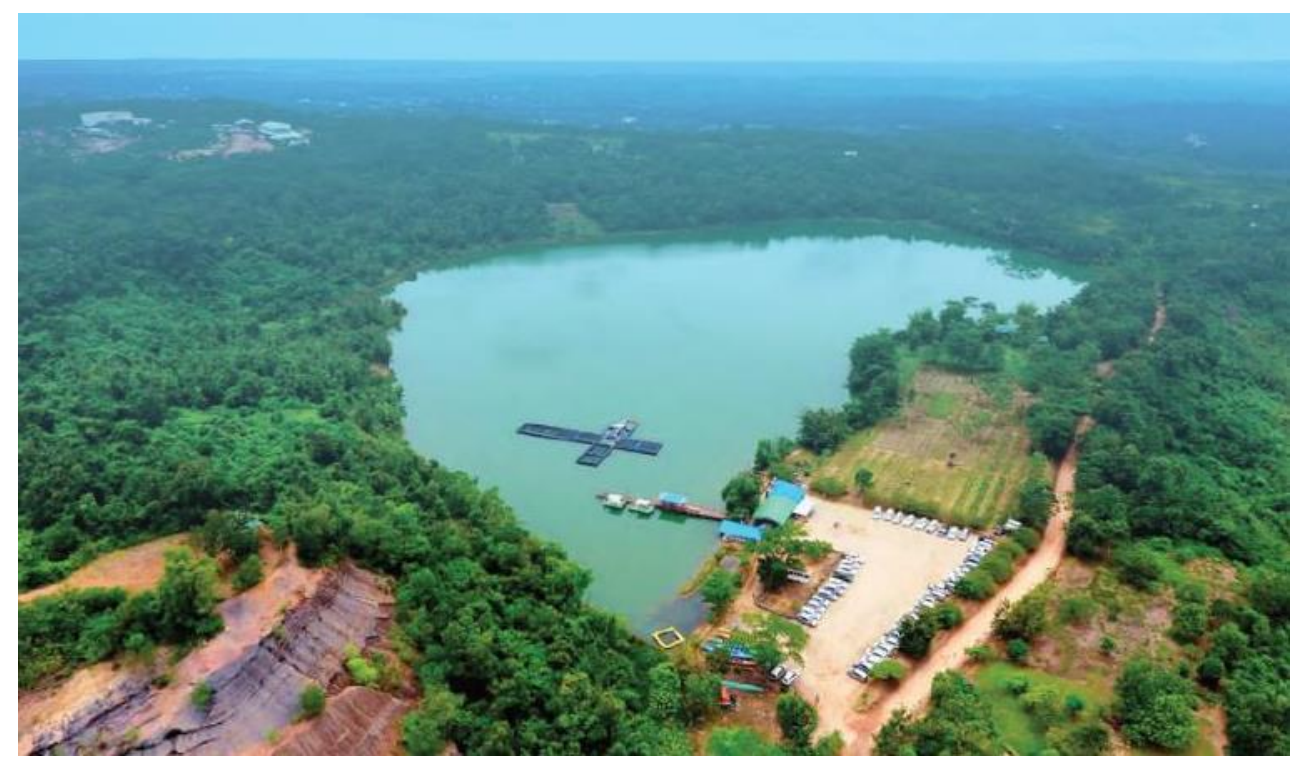

Figure 5. Lake of Batu Arang

The source of clean water from the Lake of Batu Arang which a mining plateau after was originally after leaving the pits which gradually fills with water, before it is used as clean water and submitted the Regional Water Supply Company in advance KPC perform appropriate water quality monitoring environmental quality standards to be consumed by the public.

b. Raising and Education Zone, several examples of mined land utilized for the cultivation and its function as an educational and recreational passive as follows:

1. A case study of mined land in the city of Sawahlunto that converted into fruit garden for tourism. There are various kinds of fruit cultivation developed by the department of agriculture and forestry in Sawahlunto city, and it is also for tourists to get education how process management fruit garden of mined land to be land that produces fruit and also equated provide a shopping tour fruit produce from the garden of this fruit (Arifman, et. al., 2013).

2. PT Adaro Indonesia to plant oil palm (Elaeis oleifera) and jatropha (Jatropha curcas) to produce biodiesel in a post-mining reclamation land. The biodiesel production now saves on fuel costs to support the mining operations, trucks and light vehicles that are used for production operations are usually given diesel fuel. In addition to saving fuel, biodiesel can be used as a partial replacement for the current fuel and this option is also more environmentally friendly (Mansur, 2012).

3. The former mining site of PT Berau Coal reclamation is now land for planting cocoa (Theobroma cacao), and the rubber tree (Heveabrasiliensis), cacao trees shade trees planted after (F. moluccana) has grown and grown enough to provide 
shade on the cacao tree. Rubber trees are usually used for mine reclamation at the request of landowners, both individuals, and private companies.

4. Water usage from the mine in PT Adaro Indonesia, which has been deposited in a sedimentation pond and otherwise appropriate quality standards, also, to circulate into WTP flowed well into the fish pond. Farmed fish types that Nila, Mujair and other types of fish. The fish are distributed into a community, from its seeds, and PT Adaro Indonesia also guides the way to cultivate it for economic purposes. Later this fish cultivation will be submitted to the government/society/group (Adaro Indonesia, 2013).

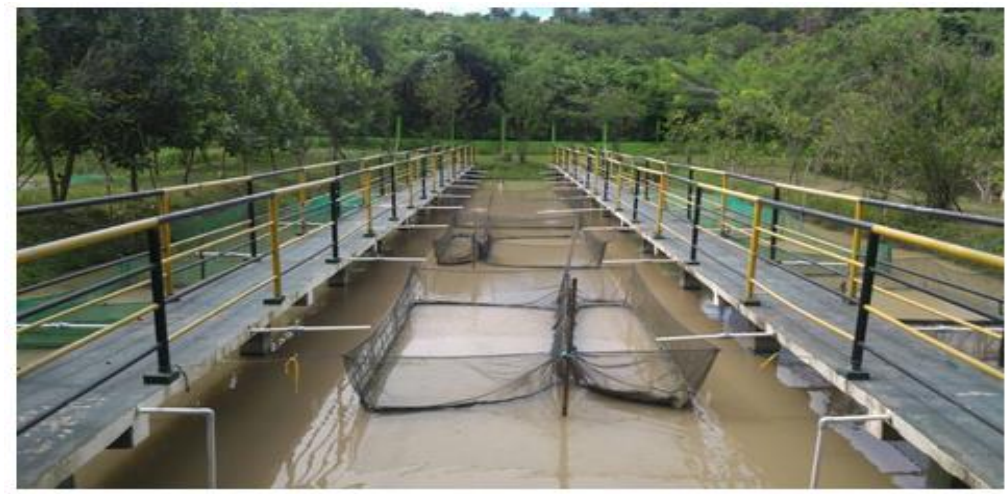

Figure 6. Aquaculture in PT Adaro Indonesia

5. Cattle Integrated Program (FAST) is one of mined land utilization program of PT Kaltim Prima Coal stands on 22 hectares of mined land. FAST is an integrated cattle farming model program and includes programs PPM KPC. Products from the dairy farms produce meat products; dairy products will produce yogurt and pasteurized milk. Meanwhile, the biogas produced from livestock manure utilized for electrical readiness, as well as organic fertilizer produced from the manure will be used for reforestation, vegetable, and forestry, so that the plants can flourish. In addition, to be the location of education, activities of KPC is the well-sustained impact of economic, social and environment for the people in the area around the mine.

6. PT Kaltim Prima Coal to develop freshwater aquaculture in Lake of Batu Arang. Similar farmed fish catfish, catfish, goldfish, and tilapia in ponds locations coking named nursery cages.

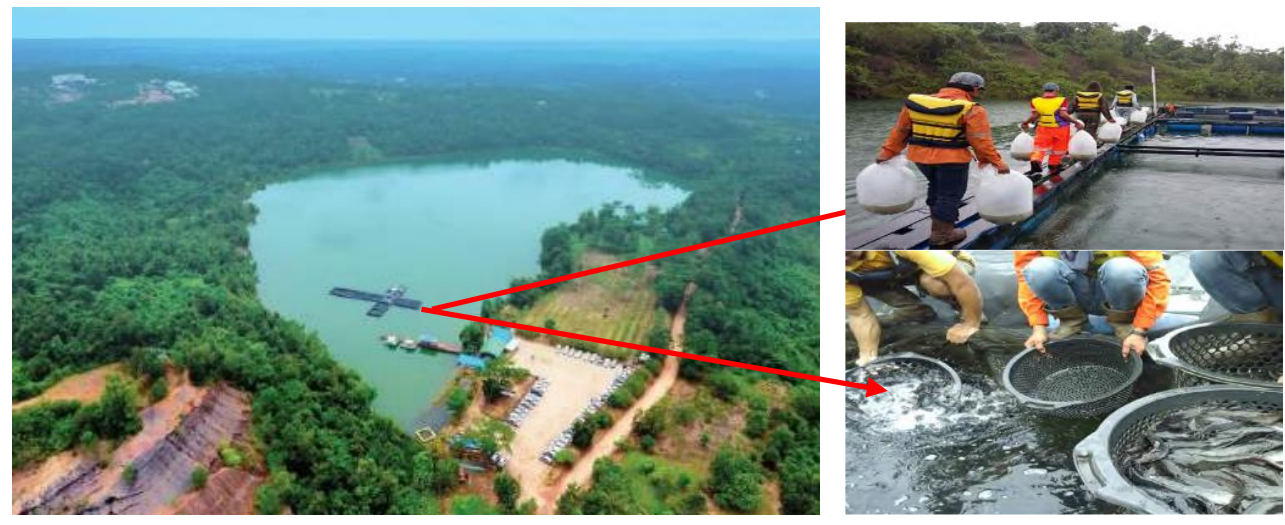

Figure 7. Separating cage (Location Telaga Batu Arang) 
7. In addition to fish farming and cattle PESAT KPC cultivation laying hens, in cooperation with the Cooperative KODIM 0909 Sanggata conducted in mined areas Pit J. In addition, the implementation of laying hens farming is still accompanied by KPC employee who is also a recipient of scholarships from the local community KPC (Kaltim Prima Coal, 2015).

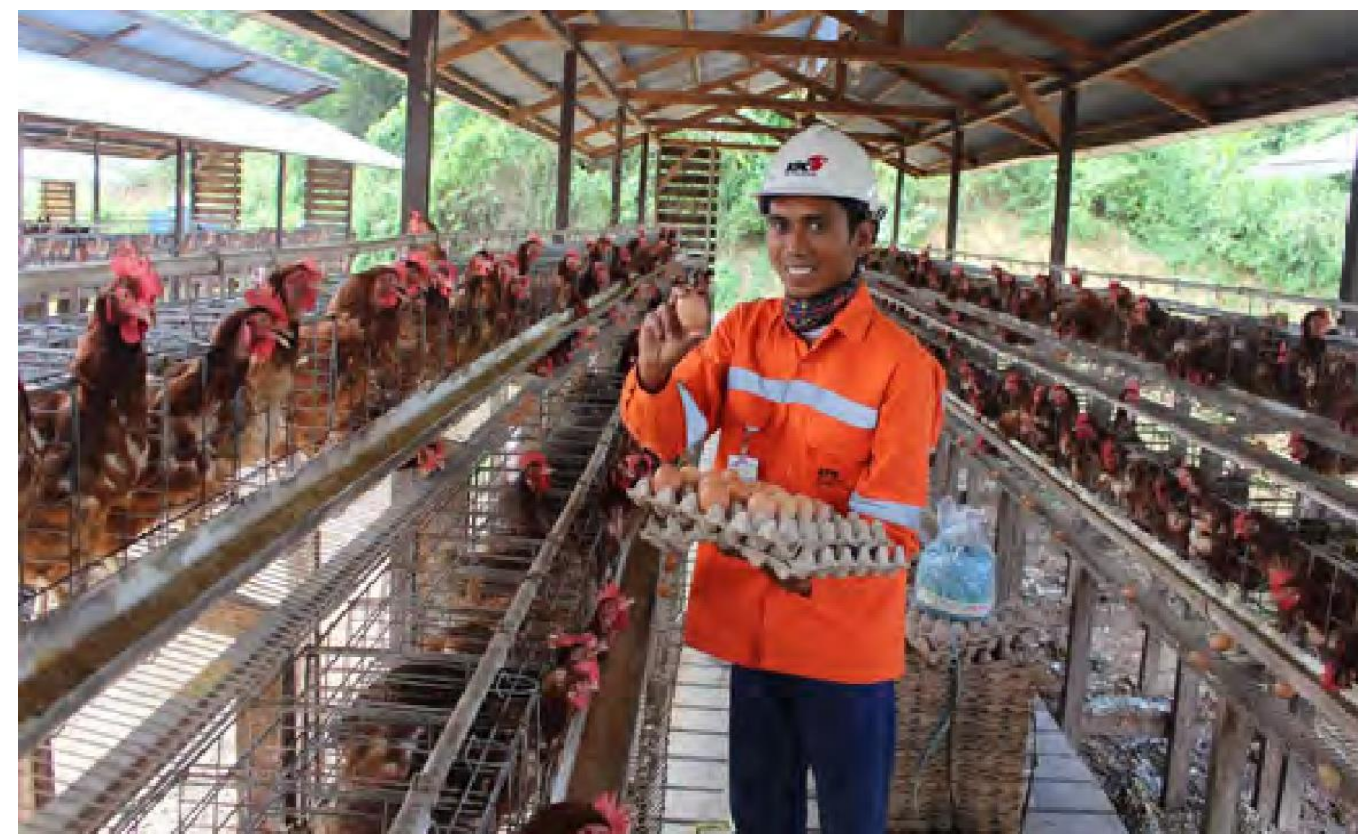

Figure 8. Utilization Pit J for Raising Poultry Laying

c. Recreation Zone, a few cases of mined land were used as a model to be developed into a recreational zone is as follows:

1. A Case Study of mined land PT Bukit Asam in Sawahlunto city, drilled area in the form of lakes used water attractions, with recreational facilities such as water bikes and rowing boats which used to surround the former mining lake surrounded reclamation of degraded forest scenery PT Bukit Asam Sawahlunto (Arifman et al., 2013).

2. Also, in the former mining area of PT Bukit Asam also be an arena Sawahlonto outbound and nature with various play facilities such as flying fox, paintball, ground games, high ropes and other games that can be played individually or in groups (Arifman et al., 2013).

d. Conservation Zone

The case study of land developed for conservation zones is as follows:

1. A case study in PT Bukit Asam Tanjung Enim, the development of the urban forest as a green space in the form of construction of the urban forest of 50 hectares in the location heap Air Laya

2. A case study in PT Bukit Asam Sawahlunto, develop tree planting for the conservation of green open space (RTH) attractions around the Camping Ground, Old Coal Mining Town, and other tourist areas to provide comfort and cool for at tourists but it also can be a water catchment area to prevent flooding.

3. A Case Study in PT KPC was developing and conserving local wildlife on mined land that has been reclaimed. In the post-mining region of 51 orangutans and other local wildlife relocated in 2016 (Kaltim Prima Coal, 2016). 


\section{e. Infrastructure Zone}

This zone is a zone that can be enjoyed by many people in the form of public facilities, roads, hospitals, schools, and examples:

1. Case Study PT Bukit Asam, which utilize mined land into infrastructure that can be utilized by the community, e.g. Building construction Sports (GOR), where Bowling, mined land that is used as an arena Golf and Futsal.

2. Utilization of the planned road hauling into regional and local road for example, in some provinces such as East Kalimantan and South Kalimantan.

3. Utilization of the mess, the guest house is an asset of local government especially on Coal Mining Agreement (PKP2B) Generation I especially like PT Adaro Indonesia, PT Berau Coal, PT Kaltim Prima Coal etc. In the contract agreement stated that all company assets will belong to the state.

From the above discussion, each company has a plan for reclamation and postmining based on their priority and environment situation. PT Kaltim Prima Coal has reclamation, and mine closure plans are already well underway in accordance zones are defined as follows:

Table 4. Post-mining land use zone of the KPC (Kalitim Prima Cola, 2016)

\begin{tabular}{ll}
\hline \multicolumn{1}{c}{ Zone } & \multicolumn{1}{c}{ Usage } \\
\hline of Protected Zone & Utilization of water and provision of resources clean water \\
\hline Buffer zones & $\begin{array}{l}\text { Utilization and restoration of biodiversity, to rehabilitate and } \\
\text { manage and develop the land into a zone after ecotourism because } \\
\text { it is directly adjacent to the Kutai National Park. }\end{array}$ \\
\hline Conservation Zone & $\begin{array}{l}\text { Utilized to develop the typical flora and fauna of the area following } \\
\text { the initial conditions and develop the new species of both animals } \\
\text { and plants according to the region. } \\
\text { Utilization and mined land development as a tourist zone that is } \\
\text { mine openings (void) developed into the lake / Lake of Batu Arang } \\
\text { for recreational activities. }\end{array}$ \\
\hline Zone Use & $\begin{array}{l}\text { Land post-mining KPC utilized and developed for the cultivation of } \\
\text { laying hens, breeding cattle (FAST: Cattle Integrated) and } \\
\text { freshwater fish farming in Lake of Batu Arang, cultivation and } \\
\text { planting grass and cassava in post-mined land area 45\% of mined } \\
\text { land KPC. }\end{array}$ \\
\hline
\end{tabular}

Source: results of data analysis, 2018

\section{CONCLUSION AND RECOMMENDATIONS}

\section{Conclusions}

From the discussion about the use of reclamation and mine closure concluded that the utilization of land reclamation and post-mining of various companies are different, such usage can be: the method of pits into water treatment, freshwater aquaculture and ecotourism, utilization reclamation and post-mining land be used as a farming plains flora and fauna such as the cultivation of laying hens, cattle, crops, and so forth. Utilization of land reclamation and mine closure should conform with the first zone and Assessment EIA Document, Kelayangan Studies, Plans Reclamation and Mine Closure Plan which has been approved in consultation with the Government, communities, and stakeholders. 


\section{Recommendations}

The result from the AHP method shows that aquaculture and ecotourism development is the priority of the strategy of post-mining land use utilization with respect to ecology, socioeconomic and cultural criteria. Through the strategy of utilization of land reclamation and mine closure environmentally sound to create a society that is sustainable both from the environmental, social and economic that can provide income from other sectors, of course, with the planning and implementation of programs of reclamation and mine closure well before the closure so as to contribute revenue to the regions.

\section{REFERENCES}

Adaro Indonesia. (2010). Coal Added Value for Sustainability. Sustainability report 2010: Sustainability Report.

Adaro Indonesia. (2013). Delivering Positive Energy Sustainably. Sustainability Report 2012-2013.

Arif, I. (2007). Perencanaan Mine Total Settlement Efforts Environmental Issues as World Mining University of Sam Ratulangi, Manado.

Cooper, A., Shine, T., McCann, T., Tidane, D.A. (2006). An ecological basis for sustainable land use of Eastern Mauritanian wetlands. Journal of Arid Environments, 67, 116-141.

Creswell, J.W. (2013). Research Design: Qualitative Approach, Quantitative and Mixed. Yogyakarta: Student Library.

Dewi, R. (2011). Landscape Planning for the Development ofNature in BorderKemiri River District of Margadana - Tegal City. PSMILUNPAD.

Gunawan, A., Jaya, I.N.S., Saleh, M.B. (2010). Quick techniques in identifying Open Area by the Use of Multi-Spatial and Multidate Imageries. Journal of Tropical Forest Management, 16(2), 63-72.

Hartman, L. H. (1987). Introductory Mining Engineering. Canada: John Wiley \& Son, Inc.

http://pmb.lipi.go.id/

Hu, D., Yang, G., Wu, Q., Li, H., Liu, X., Niu, X., Wang, Z., Wang, Q. (2008). Analyzing Land Use Changes in the Metropolitan Jilin City of Northeastern China Using Remote Sensing and GIS. Sensors 8, 9, 5449 -5465. doi: 10.3390 / s8095449.

Kaltim Prima Coal. (2015). Membara Untuk Indonesia. Sustainability Report 2015

Kaltim Prima Coal. (2016). Nyalakan Semangat Bersama Igniting Resolution. Sustainability Report 2016

Mansur, I. (2012). Integrating Biodiversity Conservation and Agricultural Production in Mine Reclamation for Sustainable Development. Journal of Developments in Sustainable Agriculture, 7, 97-102.

Nurcahyani, T. (2011). Kajian Pemanfaatan Lubang Bekas Tambang (Void) di Adaro Indonesia, Provinsi Kalimantan Selatan. Program Studi Ilmu Lingkungan, University of Indonesia.

Peterson, G. D., Heemskerk, M. (2001). Deforestation and forest regeneration following small-scale gold mining in the Amazon: the case of Suriname. Environmental Conservation, 28(2), 117-126.

Robertson, A., Shaw, S. (n.d.). Mine Closure. Info Mine E-book

Ross, S., Wall, G. (1999). Ecotourism Towards Theory and Practice. Tourism Management. 
Sandin, L. (2009). The relationship between land-use, hydromorphology and river biota at different spatial and temporal scales: a synthesis of seven case studies. Fundamental and Applied Limnology, 174(1), 1-5.

Trisasongko, B. H., Panuju, D. R., Iman, L. S., Harimurti, V. A., Ramly, A. F., Subroto, H. (2009). Analisis Dinamika Konversi Lahan di Sekitar Jalur Tol Cikampek. Publikasi Teknis DATIN, Kementerian Negara Lingkungan Hidup.

Tuni, M. S. (2013). Perencanaan Penggunaan Lahan Pascatambang Nikel untuk Mendukung Pengembangan Wilayah di Kabupaten Halmahera Timur. Tesis Program Studi Pertanian, Institut Pertanian Bogor.

Tuni, M. Z. (2013). Perencanaan Penggunaan Lahan Pascatambang Nikel Untuk Mendukung Pengembangan Wilayah Di Kabupaten Halmahera Timur. Tugas Akhir Program Studi Ilmu Perencanaan Wilayah Departemen Ilmu Tanah dan Sumber Daya Lahan, Institut Pertanian Bogor.

Undang-undang Nomor 4 Tahun 2009 tentang Pertambangan Mineral dan Batubara

Undang-Undang Nomor 41 tahun 1999 tentang Kehutanan

Zhang, et. al. (2011). Land Use-Based Landscape Planning and Restoration in Mine Closure Area. Springer Science Buisness Media.

Zhang, J. J., Fu, M. C., Tao, J., Huang, Y., Hassani, F. P., Bai, Z. K. (2010). Response of ecological storage and conservation to land use transformation: a case study of a mining town in China. Ecological Modelling, 221, 1427-1439. 